\title{
Seçim Sosyolojisi ve Lübnan'da Seçimler
}

\section{The Sociology of Election and Elections in Lebanon}

\author{
Gökhan Bozbaş, ${ }^{\text {a,* }}$ Badria Al-Rawi ${ }^{b}$
}

${ }^{a}$ Dr. Öğr. Üyesi, Necmettin Erbakan Üniversitesi Siyasal Bilgiler Fakültesi, Uluslararası İlişkiler Bölümü, 42090, Konya/Türkiye. ORCID: 0000-0003-3715-8402

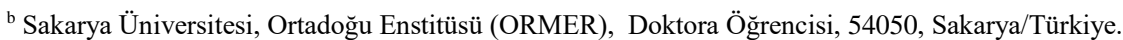
ORCID: 0000-0001-5383-682X

\begin{tabular}{l} 
MAKALE BİLGİSİ \\
\hline Makale Geçmişi: \\
Başvuru tarihi: 31 Mart 2020 \\
Düzeltme tarihi: 01 Mayıs 2020 \\
Kabul tarihi: 14 Mayıs 2020 \\
\hline Anahtar Kelimeler: \\
Seçim sosyolojisi \\
Lübnan, \\
Mezhepçilik \\
Seçmen davranışları
\end{tabular}

\section{A RTICLE INFO}

\section{Article history:}

Received 31 March 2020

Received in revised form 01 May 2020

Accepted 14 May 2020

\section{Keywords: \\ Election sociology, \\ Lebanon,}

Sectarianism

Voter behavior
ÖZ

Lübnan'da 2018 yılında 9 yıllık bir aranın ardından ilk defa seçimler yapıldı. Seçimler Lübnan'da tartışmaları bitirmemiş bilakis daha da derinleştirmiştir. Fakat bu derinleşen tartışmalar Lübnan için bir çıkış, bir üst kimlik inşa sürecine dönüşebilir. Lübnan bir asrı aşkın bir süredir bireylerin kendilerini mezhepleri üzerinden tanımladıkları bir sosyal yapıya sahiptir. Lübnan mezhepçilik kavgasından sadece içeride sorunlar yaşamamıştır. Aynı zamanda dışarıdan müdahalelere de sosyal olarak her daim açık bir yapı sunmuştur. Lübnan'da son dönemlerde ortaya çıkan yeni gelişmeler ülke içerisinde üst kimliğin inşası adına umut verici gelişmeler olmakla beraber karar alıcıların yanlış tercihleri onları daha derin çatışmaların içine itebilir. Zira Lübnan son yıllarda özellikle bazı siyasi aktörlerin mezhep üstü tercihlerle karşılaştığı bir siyasi alan olmuştur.

\section{A B S T R A C T}

In Lebanon, in 2018, after a 9-year break, the elections were held for the first time. The elections, far from putting an end to debates, it made debates deepen. However, the debates for Lebanon, may turn into a way out and an upper identity building process. Lebanon, for more than a century, has a social structure where individuals define themselves through their sects. Lebanon, not only had sectarian fight problems inside but also had an open structure to outside interventions. Although recent developments in Lebanon are promising developments for the construction of upper identity within the country, the wrong choices of decision-makers can push them into deeper conflicts. Yet, in recent years, Lebanon has been a political area, where some political actors have faced sectarian preferences.

\section{Giriș}

Lübnan'da 9 yıl aradan sonra gerçekleşen 2018 Mayıs seçimlerinin üzerinden 2 yıl geçmiş olmasına rağmen ülke siyasi sükûnete kavuşamamıştır. Duruma makro zeminde bakıldığında seçimlerin gerçekleşmesinden ancak dokuz ay sonra hükûmet kurulabildiği, bunu takiben henüz altı ay geçmeden sokaklar karıştığı ve bir milyonu aşkın insanın hükûmet aleyhine gösterilerde bulunduğu görülmektedir. Henüz bir yılını doldurmadan istifa etmek zorunda kalan hükûmetin yerine kaim olan yeni hükûmet de ancak üç aylık bir zaman diliminden sonra kurulabildiği için yeni hükûmetin başbakanın yapılmasını öngördüğü icraatlarının ilk maddesini seçim kanunu değiştirilmesi teşkil etmiştir. Lübnan'ın ahvali, ülkenin gidişatta ciddi bir siyasi krize gebe olduğunu göstermesi bir yana sonu gelmeyen bu krizlerin arkasında yatan etmenlerin ne olduğunu yönelik bir istifhamı da akla getirmektedir.

2018 Lübnan seçimleri akabindeki havadisler genel olarak değerlendirildiğinde yaşananların temelinde yer alan esas müşkülatın önemli ölçüde "temsil sorunu" olduğu

\footnotetext{
* Sorumlu yazar/Corresponding author.

e-posta: gbozbash@gmail.com
} 
görülmektedir. Son iki yıllık süreçte iki kez hükûmet kurma çabaları esnasında ortaya çıkan siyasi kavgalar bunun en net şekilde algılanması için zannımızca kâfi gelecektir. Siyasi kavgaların temelinde ülkenin etnik ve mezhebî bölünmüşlüğü yer almakla birlikte son dönemde yaşanan tartışmalar, aynı din çatısı altındaki mezhepler arası kavgaların farklı din müntesipleri arasındaki mücadele kadar derin ve köklü olduğunu göstermiştir. Nitekim seçim sonrası hükûmet kurulmasına ilişkin yaşanan tartışmalarda hangi mezhebî grubun kaç bakanla temsil edilmesi kontenjanlar önceden belirlendiği için bir sorun teşkil etmezken bu kontenjanların mezhebî-etnik gruplar arasında nasıl taksim edileceği sorunu hükûmetin teşekkülünü dokuz ay ertelemiştir.

Lübnan'da son günlerde yaşanan kimlik temelli bu çatışmaların yeni olmadığı bir gerçektir. Lübnan'ın kimlik farkındalığını hissetmeye başladığı Osmanlı'nın son dönemlerine tekabül eden 19.yüzyılın ortalarından bugüne dek bu tartışmalar sürekli devam edegelmiştir. Aslında benzer tartışmalar Orta Doğu coğrafyasındaki neredeyse bütün devletlerde mevcut olmasına rağmen her devlet içerisindeki kimlik kavgasını yorumlamak imkânsız gözükmektedir. Zira birçok ülkede iktidarı elde tutan siyasi kimlik diğer kimlikleri bastırmaktadır. Lübnan'da ise birkaç istisnai durum dışında 1922 yılından günümüze yaklaşık bir asırdır müteselsilen seçimlerin yapılması, kimlikler arası tartışmaları analiz edebilme imkânını vermektedir.

$\mathrm{Bu}$ makale Lübnan'da bugüne kadar gerçekleşen seçimleri analiz ederek ülkedeki mevcut etnik ve mezhebe dayalı kimliksel bölünmüşlüğü seçimler üzerinden açıklamayı hedeflemektedir. Zikredilecek izah ve analizler, geçtiğimiz yüzyıl kavramsallaştırılmış olan ve siyaset sosyolojisinde önemli bir yer edinen seçim sosyolojisi üzerinden gerçekleşecektir. Zira Lübnan'da seçim sosyolojisi denildiğinde Lübnan halkının siyasal tercihleri anlaşıldığ gibi bu kavram, aynı zamanda ülkenin kültürel fay hatları temelindeki etnik ve mezhebe dayalı sosyolojik bölünmüşlüğüne de karşılık gelmektedir. “Lübnan’da günümüz sekteryan bölünmüşlük hangi tarihi temellere dayanmaktadır?", "Lübnan'da asırları aşan temsil sorunu hangi nasıl bir değişim ve dönüşüm yaşamıştır?” gibi sorular, Lübnan'da bugüne kadar gerçekleşen seçimler merkeze alınarak analiz edilmeye çalışılacaktır.

\section{Teorik ve Kavramsal Çerçeve}

Sosyal Demokratik kültüre sahip olduğu düşünülen ülkelerin hemen hemen tamamında periyodik olarak serbest ve adil seçimler yapılmaktadır. $\mathrm{Bu}$ ülkelerdeki mevcut siyasi otoritenin meşruiyeti ise bu seçimlerin yapılıp yapılmadığı ve yine seçimlerin ne derece özgür ve adil olduğu ile orantılıdır. Seçimler demokratik yollarla gelen yasa koyucu güç ile temsilciler üzerinden halkla bir bağ inşa etmektedir. $\mathrm{Bu}$ sebeple seçimler seçilmişlerin eylemlerini kontrol etmek ve siyasal elitleri barışçıl yollarla değiştirmek için kurumsallaşmış bir yol sunmaktadır. Seçimler sadece siyasal seçkinlerin nasıl seçileceği ile alakalı bir şablon vermez, aynı zamanda seçmen davranışlarını da yazılı, standartlaştııılmış ve önceden yapılandırılmış elit bir davranış hâline getirmektedir (Schmitt, 2005).

Günümüz dünya ülkeleri arasında halkın seçtiği temsilciler parlamentolarda toplanarak halk adına kararlar almakta ve bu anlayış temsili demokrasi olarak adlandırılmaktadır.
Temsilî demokrasilerin merkezinde bulunan siyasi katılımın en yaygın biçimi olarak oy verme davranışı görülmektedir ve bu durum seçim sosyolojisinin en temel konusudur. Günümüzde birçok ülkede düzenli olarak seçimler gerçekleştirilmektedir. Bu seçimler özellikle sosyologlar ve siyaset bilimcilerin geliştirdikleri birtakım yaklaşımlar aracılığı ile seçmenlerin sosyal ve siyasal yapılara dayalı davranışlarını açıklamaya çalışmaktadır. Konuya ilişkin yaklaşımlar incelendiğinde ise temelde üç farklı modelin ön plana çıktığı görülmektedir (Schoen, 2009: 181-188). Birinci model özellikle Kolombiya okulundan Paul Lazarsfeld' in sıklıkla kullandığı ve ön plana çıkardığı mikro sosyolojik yaklaşımdır (Manza ve Brooks, 1999: 12). İkinci olarak Lipset ve Rokkan tarafından yoğun bir şekilde kullanılmış olan makro sosyolojik yaklaşımlar seçmen davranışlarını yorumlayan ve değerlendiren temel anlayışlardandır (Lipset ve Rokkan, 1967). Son olarak kullanılan üçüncü yaklaşım ise sosyo-psikolojik anlayışa dayanmaktadır.

Mikro sosyolojik yaklaşım açısından önemli olan, seçmenler üzerinde birincil grupların ve yüz yüze etkileşim içerisinde bulundukları yakın aile, meslektaşları ve yakın arkadaşlarının etkilerini incelemektedir. $\mathrm{Bu}$ yaklaşımı benimseyenler özellikle sosyopolitik davranışlarını bu birincil grup baskılarına göre adapte ettiklerini varsaymaktadır. Burada örneğin aile babası ve ailedeki baskın karakter, seçmenin sosyal ortamında tercih edilen partiyi belirleyecektir. Sonuç olarak aynı sosyal çevre içerisinde bulunmak aynı veya benzer seçmen davranışı sergilemeye neden olmaktadır.

Mikro sosyolojik yaklaşımın yanı sıra seçmen davranışlarının değerlendirildiği bir diğer önemli yaklaşım ise özellikle toplumdaki temel çıkar çatışmalarının analiz edildiği ve bu çatışmaların dengelenmesi çabalarını değerlendiren makro sosyolojik yaklaşımdır. Bu makro yaklaşımda ise iki temel anlayış vardır: Bunların ilki daha çok ulusal bir anlayışla merkez ve çevre arasındaki çatışmaları daha çok etnik, bölgesel, kültürel çatışmalar ve mezhebî bölünmüşlüklerin belirlediği siyasal davranışları incelemektedir. İkinci makro yaklaşım ise daha çok sosyoekonomik ve sınıfsal çatışmaları analiz ederek politik davranışları değerlendirmektedir. Makro sosyolojik yaklaşımın sınıfsal çatışmaya dayanan bu anlayışı, aslında toplum içerisinde var olan çatışma durumuna göre bir çerçeve çizerek bireylerin kendi ideolojik ve sınıfsal gruplarına göre bir siyasal davranış gösterdiğini iddia etmektedir.

Seçmen davranışlarının analizinde kullanılan üçüncü yaklaşım ise sosyopsikolojik anlayışa dayanır ki bu yaklaşım, özellikle Michigan Üniversitesi'nde Angus Campbell tarafından son dönemlerde geliştirilen bir araştırma ile yaygınlaşmıştır. $\mathrm{Bu}$ yaklaşım, seçmen davranışlarını özellikle adayların özellikleri, dönemlik tartışmalara yönelik politikacı davranışları ve bunlar ile bağlantılı olarak ortaya çıkan bir parti kimliği üzerinden açıklamaktadır. Bu yaklaşım yine parti kimliğinin oluştuktan sonra daha uzun vadeli bir tercihi belirleyici olarak görürken aday ve konu tercihlerini ise daha kısa vadeli bir değişken olarak değerlendirmektedir. 


\section{Osmanlılar Döneminde Cebel-i Lübnan ve Siyasal Katılım}

Osmanlılar döneminde Cebel-i-Lübnan olarak bilinen bugünkü Lübnan topraklarına bölge halkı sadece Cebel demektedir. İki kavramında kastettiği aslında bugünkü Lübnan'dır. Lübnan denildiğinde Orta Doğu toplumları içerisinde etnik ve dinî açıdan en karışık topraklarından birisi akla gelmektedir. Ülke halkının sahip olduğu dinî ve kültürel bölünmüşlüğü bu karmaşık nüfus yapısının kendi aralarındaki çatışmalarının da başlıca sebebidir. Osmanlı İmparatorluğu'nun son dönemlerinde Fransızların ilgi alanına giren bu topraklar, Osmanlı'nın dağılmasından sonra Fransız mandası olmuş ve İkinci Dünya Savaşı esnasında 1943 yılında bağımsızlığını kazanmıştır.

Ülkenin dağlık olması ise onun karmaşık olan bu sosyopolitik ve dinî yapısını daha da komplike bir hâle getirmiştir/getirmektedir. Tarihî olarak Lübnan denince akla aslında iki grup gelmektedir: Bunların birincisi Lübnan'daki en büyük nüfusa sahip olan Maruni Kilisesi'ne bağlı Hristiyan-Katolik grup olan Marunilerdir. Maruniler sadece Lübnan değil, bugün aynı zamanda Filistin ve Kıbrıs'ta da bulunmaktadırlar. Lübnan'da geleneksel olarak yaşayan ikinci grup ise Müslümanlardır. Bazı kaynaklar İslamiyet'in Şiilik mezhebinin İsmailliye kolundan doğan olan Dürzileri de Müslüman grubun içine katarken bazı kaynaklar onları müstakil bir çerçevede ele almaktadır (Bağlığlu, 2008).

Osmanlı'nın güçlü olduğu dönemlerde dahi birçok mezhebe dayalı tartışmaların yaşandığı bu bölge, özellikle 19.yüzyılın ortaları ile birlikte birçok kanlı çatışmanın merkezi konumuna gelmiştir. 1840-1861 yılları arasında yaşanan çatışmalar, Osmanlı otoritesinin bu bölgede ilk defa mezhebe dayalı esaslara dayanan birtakım yönetim şekillerine başvurmasına sebep olmuştur. $\mathrm{Bu}$ yönetim şekilleri aslında bugünkü seçimlerin ve temsil mekanizmasının geliştirilmesinin de ilk örneklerini teşkil etmesi bakımından önem arz etmektedir (Mo’az, 1968).

Lübnan'daki Maruni nüfusu 18.yüzyıldan itibaren Şihabi Sünnîlerin ve Lam Dürzilerin Hristiyanlaşmasıyla birlikte artmaya başlamıştır. Aslen Sünni Müslüman olan Şihab ailesi, özellikle Dürzîler ile çok ciddi çatışmalar yaşamıştır. $\mathrm{Bu}$ durum onları önce Marunilere yakınlaştırmış ve daha sonra Hristiyanlaşmalarına sebep olmuştur. Aile, 18.yüzyılın sonunda Hristiyanlığı kabul etmiş ve iktisadi konumlarını güçlendirmek için Avrupa'dan gelen Hristiyan göçmeleri desteklemişlerdir. Hatta bu durum belli bir dönem sonra Fransızların gelmesiyle onların bölgedeki etkinliklerini arttırma gayretine dönüşmüştür. Şihabilerin yanı sıra yakın dönemlerde Lübnan'ın önemli Dürzî ailelerinden Ebu'l-Lam mensupları da Hristiyanlığa geçtiler. Özellikle Emir Beşir Şihabi döneminde Dürzî emirlerin hoşgörü ve destekleri ile misyonerlerin faaliyetleri artmış ve bu ailenin dışında birçok Dürzî de Marunîlere katılarak Hristiyanlaşmıştır. Bu dönemde yaşanan bir dizi yerli, bölgesel ve uluslararası olaylar neticesinde Maruni kilisesi Lübnan'1n sosyal, siyasi, kültürel ve ekonomik hayatında büyük role sahip olmaya başlamıştır (Deringil, 2012: 179).

1861 yılı öncesi Lübnan'ın sosyopolitik yapısını ifade eden en önemli kurum Arapçada lider anlamına gelen 'zaimlik'tir. Zaimlik veya çoğulu olan zuema sistemi, aslında bizdeki toprak ağalığı sisteminin bir benzeri hatta aynısıdır. Lübnan özelinde değerlendirildiğinde bu kurum, olağan şeklinden daha fazla geliştiği söylenebilir. Güçlerini doğrudan ağadan alan zaimler, Osmanlı'nın buradaki otoritesinin sağlanmasında da aktif rol üstlenmişlerdi. Özellikle 1840 yılı bu noktada oldukça önemlidir. Zira güçlenen Marunî topluluğu, gerek demografik, sosyal ve ekonomik gelişmeler neticesinde gerekse o dönem Misır valisi Muhammed Ali'nin yenilgiye uğratılmasıyla Avrupa'dan aldıkları cesaretle Marunî Patrik'i Yusuf Habeş'in (1823-1845) öncülüğünde Marunî özerkliği talep etmiştir. Patrik, Fransa aracılığıyla Osmanlıdan yine çeşitli dinî, sosyal, kültürel, ekonomik ve idari isteklerde bulunmuştur. Talep edilenler arasında konumuz açısından en dikkat çeken husus, Lübnan'da 12 üyesi olan ve bu üyelerin müsteşar sıfatını taşıyacağı bir meclis ile anayasal bir sistem oluşturulmasıdır (Harîk, 1982: 123). Bu taleplerin hiçbiri 1861 yılına kadar sürecek olan iç çatışmalardan dolayı gerçekleşmemiştir. Aslında bu zaimlik sistemi seçim sosyolojisi bakımından bireylerin temel davranış kalıplarını yüz yüze etkileşim içerisinde bulundukları grupların belirlediğini söyleyen teorik anlayışı doğrulayan bir yapısallık doğurmaktadır. Zira zaimler genellikle güçlü ve baskın ailevi ve aşirete dayalı bir yapı inşa etmektedir. Nitekim bu ailevi yapıların ileride seçmen davranışlarını nasıl etkilediği görülecektir.

1840 yılında ortaya çıkan ilk dönem çatışmalarında Lübnan'daki Marunilerin özerklik talepleri ve Fransa'nın da baskıları ile 1843 yılında ikili bir kaymakamlık sistemi ihdas edilmiş (Keleş, 2008), Lübnan'ın kuzeyi Maruniler ve güneyi ise Dürziler tarafından seçilmiş bir kaymakam tarafından yönetilmesi kararlaştırılmıştır. Bu sistem 1861 yılında ortaya çıkacak olan kanlı iç çatışmaları engelleyememiş, yönetim ve temsil sisteminde bir değişikliğe gidilmiştir. Arap kaynaklarında 1800'lü yıllara atfen 'atmış olayları' (Havâdi's-sittîn) olarak geçen bu çatışmalar akabinde soruşturma yapma amacıyla Fransa, İngiltere, Rusya, Prusya ve Avusturya'nın içinde bulunduğu beşli bir komite görevlendirilmiştir. Beyrut ve İstanbul'da gerçekleştirilen toplantıların sonucunda Lübnan'da uygulanan kaymakamlık sistemi kaldırılmıştır (Duman, 2007).

1861 yılında son olarak Türk kaynaklarında "Beyoğlu Protokolü" olarak geçen anlaşma ile Lübnan, Avrupalı devletlerin tavsiyesi ve Osmanlı otoritesinin ataması ile Lübnanlı olmayan Hristiyan bir mutasarrıf tarafindan yönetilmeye başlanmış, Lübnan'da yaşayan cemaatlerin temsil edileceği 10 kişilik bir istişare meclisinin de bu mutasarrıfa yardımcı olacağı kabul edilmiştir. Lübnan, bu protokol ile Osmanlı vilayetleri arasında ayrıcalıklı bir statü kazanmış ve bu hüviyetini 1920 yılında Fransızlar tarafından tam olarak işgal edilene dek sürdürmüştür (Çelik, 2012: 126). 1864 y1lında tekrar düzenlenen bu protokol, Cebel-i Lübnan mutasarrıflık sistemi içerisinden Beyrut, Bekaa, Trablus ve Seyda kazalarını muaf tutmuştur. Bu esas nizam ile Cebel-i Lübnan artık Eş-Şof, El-metin, Kesrevan, ElBetron, El-Kura, Jezin ve Zahle olmak üzere yedi ilçeden müteşekkil hâle gelmiş, yeni bir düzenleme ile Daru'lKamar müdürlüğü de bu alana dahil edilmiștir. Lübnan'ın ilk mutasarrıfı olarak Katolik bir Ermeni Davut Paşa tavzif edilmişken çok kısa bir zaman sonra Arap Hristiyanlarından Franko Paşa bu göreve tayin edilmiştir (Arselân, 2011: 39; Duman, 2006 ).

Zaimlik sonrası kaymakamlık ve mutasarrıflık sistemleri Lübnan'daki siyasi olayları aslında mikro seviyeden daha 
makro bir seviyeye doğru evrilmesine sebep olmuştur. Zira bireyler kendi aileleri ve aşiretleri üzerinden birtakım tutum ve davranışları belirlerken yeni sistemleri bireyleri mezheplerine ve etnik orijinlerine göre sınıflandırmıştır. $\mathrm{Bu}$ durum uzun vadede bireylerin kendi ideolojik ve sınıfsal gruplarına göre bir siyasal davranış kalıbı içerisine sokmaya başlayacaktır.

Cebel-i Lübnan yönetimi mutasarrıfın yanında halkı temsil eden 12 kișilik bir meclis ihdas etmiştir. Bu protokolün ilk hâli olan 1861 nüshasının ikinci maddesi, Cebel-i Lübnan'da yaşayan Maruni, Ortodoks Rum, Katolik Rum, Dürzi, Müslüman ve Metavle (Şiiler) gibi 6 farklı grubun eşit sayıda temsilini öngörmüş (Heraclides ve Dialla, 2015: 141), buna göre toplumdaki nüfus oranına bakılmaksızın her bir grubun 2 üye ile mecliste temsil edilmesi kararlaştırılmıştır. 6 Eylül 1864 tarihinde protokole getirilen düzenleme çerçevesinde nüfus ile temsilci sayısı orantılanmış, bu doğrultuda mecliste 4 Maruni, 3 Dürzi, 3 Ortodoks ve Katolik Rum, birer tane de Sünni ve Şii temsilcinin olması kararlaştırılmıştır (Cobban, 2019: 35-61). 1868 yılında yapılan yeni bir düzenleme ile Daru'l-Kamar bölgesi adına tayin edilen beşinci Maruni üye ile Hristiyan üye sayısı sekiz, Müslüman üye sayısı ise beşe yükselmiştir. Bu mecliste yönetim kurulu başkanı genelde mutasarrıf tarafindan Marunîler arasından seçilir, oy kullanamaz ve mutasarrıf adına toplantılara başkanlık ederdi (Tarbîn, 1967: 347). Bu düzenlemeler Lübnan'da yaşayan halkı daha makro düzeyde keskin bir şekilde sınıflandırarak temsil edilmelerinin yolunu açmıştır. Toplumda yaşayan bireylerin muhatabı artık devlet değil kendi mensup oldukları etnik ve mezhebi grupların temsilcileri olmuştur. Bu durum Lübnan'da günümüze kadar çözülemeyecek olan bir kutuplaşmanın başlangıcıdır.

Fransızların Lübnan'1 bütünüyle işgal ettiği 1920 yılına kadar bu sistem geçerliliğini sürdürmüştür. Bu döneme tarihi bir perspektiften bakıldığında bölgedeki siyasi çatışmaların mutasarrıflar ile bölgelerin önde gelen kișileri arasında gerçekleştiği söylenebilir. Özellikle Hristiyanların ve yabancı ülke konsoloslarının her türlü müdahale ve baskı kurmaya yönelik çabaları dikkat çekmektedir. Çatışmaların temelinde ise daha ziyade Hristiyan ve Dürzîlerde çok baskın bir şekilde görülen, bireylerin kendi mezhebî gruplarına olan aşırı taassubiyeti ve bu bağlılığın bir üst kimlik inşasına engel oluşu yer almaktadır. Ayrıca oluşturulan istişare meclisine gönderilen üyelerin de bu mezhebî kimliğe göre belirlenmesinin, Lübnan'ın bugünkü siyasal katılımına ve tercihlerine etki edecek kadar derin bir izdüşümü olmuştur. Çünkü her mezhebî ve etnik topluluk, kendisine karşı olan veya olduğunu algıladığı ötekilerine karşı kendi nüfuzunu güçlendirmek için çalışmaktaydı.

\section{Fransız Mandası Lübnan ve Siyasal Katılım}

General Henri Gouraud 01/09/1920 yılında Beyrut, Trablus, Seyda, Sur ve Bekaa ilçelerini Cebel-i-Lübnan'a dâhil etmek suretiyle bugünkü modern Lübnan haritası belirlenmiştir. $\mathrm{Bu}$ birleşme, Osmanlılar döneminde demografik yapı nedeniyle Hristiyan, Dürzi ve Müslümanlar arasında mevcut olan siyasi ayrılıkları iyice derinleştirmiştir. Daha kuruluş aşamasında ortaya konan harita üzerinde dahi Lübnan halkı anlaşamamış, "Suriye bağlanmak" ya da "müstakil bağımsız bir devlet olmak" şeklinde tezahür eden iki tercih üzerinde ciddi tartışmalar vuku bulmuştur. Balebek, Bekaa, Hasbeyya ve Raşeyya bölgelerinde bulunan Müslümanlar tam bağımsızlık fikri karşıtı olarak Suriye'ye bağlanmayı tercih etmiş, Emir Faysal'a lider olarak biat etmişlerdir. Çoğunluğunu Cebel-i-Lübnan sakinlerinin oluşturduğu Hristiyan nüfus ise Lübnan'ın bölgeden ayrılmasını ve Fransız himayesinde bir bağımsızlık talep etmişlerdir (ErRabî', 2014: 212,213).

$\mathrm{Bu}$ tartışmalar ve Cebel-i Lübnan'in geleceğinin konuşulduğu 1919 Paris Barış Kongresi'ndeki Marunî heyetin istekleri ve savları, günümüze kadar süren seçim ve temsil problemlerinden farklı değildir. $\mathrm{Bu}$ görüşmelerde Marunilerin temel istekleri şu doğrultudadır (Rezzak, 1998: 44,45):

1- Osmanlı Devleti döneminde Lübnan'dan ayrılmış bölgelerin tekrar Lübnan'a bağlanması,

2- $\quad$ Lübnan devletinin tam bağımsızlığının tanınması ve uygun rejimini seçmesi,

3- Nüfusa orantılı, temsile dayalı bir parlamento tesis edilmesi (bu istekleri 2017 yilına kadar devam etmiştir),

4- Fransa'nın Lübnan'da bağımsızlı yanlısı hükûmete destek vermesi.

$\mathrm{Bu}$ kongre, devletin henüz kuruluş aşamasında Lübnan toplumunda mezhebe dayalı ve kültürel bölünmüşlükler kaynaklı ciddi bir ayrışma söz konusu olduğunu göstermektedir. Ülkenin günümüz meselelerinde de bu ayrışmaların yansımasının olduğu bir gerçektir. Paris'teki barış görüşmelerinde tam bağımsızlık isteyen grup Marunîler olmasına rağmen Fransız mandasını zaruri görmelerini, savlarını Fransa gibi bir kuvvet desteklemediği takdirde dâhilî bölünme ve çatışmaların kaçınılmaz olacağına ilişkin endișeleriyle izah etmek mümkündür. Diğer yandan Lübnan'ın Arap milliyetçiliğinin ilk mayalandığı topraklar olması hasebiyle o dönemde Arap birliğini savunan bir Pan-Arabist bir bölünmenin de varlığı Marunîler arasında önemli bir korku sebebi olduğu ifade edilmelidir. Barış görüşmelerinde özellikle dinî kimlikleri ile ön plana çıkan Sünniler Suriye ile birleşmeyi tercih ettiklerini deklare etmişler (Salîbî, 1996: 205), Şii Müslümanlar ise herhangi bir tarafi zikretmemiş olsalar da kaynaklarda zikredildiği üzere aslında Kral Faysal'ın çatısı altında bir araya gelmeye sıcak baktıklarına dair birtakım işaretler vermişlerdir (Şuayb, 1987: 72).

Fransız mandası altında ilk parlamento seçimleri 1922 yılında gerçekleştirilmiştir. $\mathrm{Bu}$ seçimlerde Fransızlar, temsilcilerin etnik gruplara ve kabilelerin gücüne göre seçilmesini sağlayarak toplum içindeki çatışmayı daha da derinleştirmiş, öyle ki bazı verilere göre Fransızlar aynı etnik gruplar arasında var olan farklılıkları dahi gündeme getirmiştir (Ziemer, 1978: 609).

1922 seçimlerinde doğrudan bir partinin varlığından söz etmek imkansızdı. 30 üyeden müteşekkil bu ilk parlamentoda Beyrut için seçilen 5 milletvekili statüsünün ikisi Sünnilere, birer de Marunî, Rum Ortodoks ve azınlık gruplara verilmiştir. Bekaa için belirlenen 6 temsilcilik görevinin ise ikisi Şiilere, birer tane de Rum Ortodoks, Rum Katolik, Maruni ve Sünnilere verilmiştir (Nisan, 2017:32). $\mathrm{Bu}$ meclis 1925 yılında Fransız yüksek komiseri General Sarrail tarafından feshedilmiştir. Fesih sebebi ise Suriye, Lübnan, Alevi ülkesi, Dürzi dağı, bölgelerinde devlet başkanlığı için yapılan seçimlerde aday sunulamamasıdır. Asıl sebep, seçimlerde Müslümanların da desteğini alan, 
Fransızların bölgedeki varlığına karşı çıkan Marunî Bişara Huri'nin seçilmiş olmasıdır (Baaklini vd. 1999: 80,81). Peşi sıra teşekkül eden bütün parlamentolar bu şekilde devam ettiği Lübnan'da Fransız mandasının doğrudan etkisi altında kalınmış, sunulan her yasa teklifi Fransızların keyfî kararlarına bağlı kalmıştır.

İlk dönem seçimlerinin özellikle fesih sonrası süreçteki ortak özelliği, Müslüman cemaatlerin çoğunluğunun seçimlerde zorlama ve baskı olduğu iddiası ile seçimleri boykot etmiş olmalarıdır. İstatistikî verilere göre bu dönemde yapılan seçimlere katılımın, genellikle kayıtlı seçmenlerin üçte biriyle gerçekleştiği yönündedir (Beyhem, 1968: 130). İkinci Dünya Savaşı'na kadar Fransızların etkisi altında teşekkül eden temsilciler meclisinin birçoğu, bu şekilde boykotlar ve Fransızların baskısı altında devam etmiş, bu durum nihai noktada özellikle cemaatler, mezhepler ve etnik gruplar arasındaki mevcut kutuplaşmaları keskinleştirmiştir. $\mathrm{Bu}$ dönemin genel özelliklerine bakıldığında uzun dönemde iç savaş ve sonu gelmeyen etnik çatışmaların mayalandığı devir olmasına taaccüp etmemek gerekir.

Bu dönemi takiben 1943'te kurulan 1947 yllına dek görev yapan temsilciler meclisi çok önemli bir misyon üstlenmiş ve neticede Lübnan'ı bağımsızlığa götüren meclis olarak kayitlara geçmiştir. Bahsi geçen tarihi kapsayan İkinci Dünya Savaşı dönemi, bu bölgeleri daha önce paylaşmış olan Fransa ve Birleşik Krallığın bir rekabete giriştiği dönem olarak dikkat çekmektedir. Bu durum Lübnan üzerinde de tesirini göstermiş, Fransa'nın etkin olduğu Lübnan'a nüfuz edebilme gayesini taşıyan İngilizler, Fransızlara muhalif grupları örgütleme çabasına girişmişlerdir. $\mathrm{Bu}$ durumun, hâlihazırda zaten bölünmüş ve kutuplaşmış olan toplumda yıkıcı etki yaparak mevcut etnik kimlikleri daha da keskinleştireceği kaçınılmazdır.

Bu küresel çatışmanın gölgesinde 1943 yılında Lübnan'da önemli bir parlamento seçimi düzenlenmiştir. Seçimlerde bir tarafta Fransa'ya bağlı olan ve Lübnan'ın müstakil bağımsız bir Arap devleti yerine Fransızların himayesinde Hristiyan bir devlet olmasından yana olan Emile Edde ve kurduğu "Ulusal Blok" (el-Kütletü'l-Vataniyye) bulunmakta iken bu blok karşısında İngiliz yanlısı, Arap milletçiliği akımından etkilenmiş ve geçmişte başbakanlık da yapmış olan Bişara Huri ve onun temsil ettiği “Anayasal Blok" (el-Kütletü'dDüstûriyye) bulunmaktadır. Bu iki grup arasında özellikle bağımsızlık öncesi 1943 yılında yaşanan rekabet, Lübnan toplumunda hâlen tartışma konusudur. Huri'nin seçimi kazanması ile Lübnan manda yönetiminden kurtulmuş olsa da seçim öncesinde yaşanan siyasi kavgalar toplumsal bir çatışmaya evrilmiştir (Zamir, 2014: 92-101). Diğer yandan bu dönemde zaten etnik ve mezhebî olarak bölünmüş olan Lübnan toplumunun, İsrail Devleti'nin kurulması ve Filistinlilerin göçe zorlanmasıyla çok sayıda Filistinliyi kabul etmek zorunda kaldığı da özellikle belirtilmelidir.

\section{Bağımsızlık Sonrası Lübnan Seçimleri}

Çalışma 22 Kasım 1943 tarihinde bağımsızlığını kazanan Lübnan'da birinci parlamento seçimleri 1947 yılında gerçekleşmiştir. Ardından 1951, 1953, 1957, 1960, 1964, 1968, 1972 yıllarında yedi kez seçim düzenlenmiştir. 1972 y1lı seçimlerinde oluşan meclisin görev süresinin iç savaş nedeniyle 8 kez uzatılarak görev süresinin 1992 yılına kadar 20 yıl devam etmiş olması bir yana müteselsil olarak gerçekleşen seçimler Lübnan'da bağımsızlık sonrasında düzenli bir seçim kültürünün geliștirildiğinin göstergesi olarak kabul edilebilir. Genel olarak bakıldığında Lübnan'ın ilk dönem bütün seçimlerinde Dürzi kökenli, Arap milliyetçisi ve sosyalist Canpolat, ikinci cumhurbaşkanı Kamil Şemun' un da tabi olduğu Marunî aile Şemunlar, Rum Ortodokslarından el-Murr ailesi, Sünni Hariri, Şii Hamada ailesi ve son olarak Marunî Huri ailelerinin varlıkları ve etkileri dikkat çekmektedir.

Çok fazla dinî, mezhebi ve etnik grubun birlikte yaşadığı Lübnan'daki politik yap1, 1943 yılında Lübnan toplumunun toplum sözleşmesi olarak da nitelendirilebilecek ülkenin kurucu belgesi olarak tanımlanan Ulusal Pakt ile şekillendirilmiştir. Bu ittifaka göre Marunî toplumundan bir Hıristiyan cumhurbaşkanı, Sünni toplumunu temsilen bir Müslüman başbakan olacak meclis başkanı da Şii Müslümanlardan tayin edilecektir. Ulusal Pakt' ta zikredilen son önemli husus ise meclis üyelerinin Hıristiyanlar ile Müslümanlar arasında 6'ya 5 nispetinde paylaştırılmasıdır.

1947 yılı seçimleri önceki dönemlere kıyasla \%61 gibi bir oranla seçmen katılımının yüksek olduğu ve bağımsız adayların daha fazla meclise girdiği bir seçim olarak karşımıza çıkmaktadır. Bu seçimlerde daha önce belirlenmiş olan 55 milletvekili sayısı değiştirilmemiş olmakla birlikte Lübnan tarihinde yolsuzluğun en çok konuşulduğu seçimler olmuştur. $\mathrm{Bu}$ seçimlerde 25 tane toprak ağasının parlamentoya girdiği düşünüldüğünde aslında güçlü aile yapısının siyasette ne kadar etkili olduğu anlaşılacaktır (Landau, 1961: 129 ). Bu durum aslında seçim boykotlar ile paralel bir durumdur. Seçimi makro düzeyde mezhebi veya etnik bir grubun boykot etmesi durumunda mikro aktörler ortaya çıkarak seçimlerde bağımsız olarak meclise girmektedir.

1951 yılında yapılacak olan seçimler için bir yıl öncesinde seçim yasasında bir değişiklik yapılmış ve parlamento üye sayısı 55'ten 77'ye çıkarılmıştır. 1953 yılında 44'e indirilip 1957'de 66'ya, daha sonra yapılan başka bir düzenleme ile 99'a çıkarılmıştır. Yapılan tüm düzenlemelere rağmen Lübnan parlamentosundaki mezhebe ve etnik duruma dayalı sistem hiçbir zaman değişmemiştir. Lübnan parlamenter sistemi özellikle Fransız dinden bağımsız ve laik sistemine dayalı bir şekilde meydana getirilmiş olmasına rağmen siyasal sistemlerin Batı'da geçirdiği evrim burada yaşanmamıştır. Lübnan sisteminde dinî yapının ve soy bağının siyasal yapıda temel belirleyici etki olması hiç değişmemiştir (Çelik, 2019: 63,64).

Dine dayalı olarak geliştirilen bu sistem Hristiyan ve Müslümanlar arasında bir dengeye kavuşturulmuş olmasına rağmen dinlerin kendi içindeki mezheplere daha farklı oranlarda dağıtılmıştır. Bununla beraber mezhepler arasında dağılımlardan dolayı özellikle Hristiyanlar içerisinde Marunilerin ülke içerisinde genele oranla çok daha fazla avantajlı bir hâle gelmiştir. Bu baskın karakter özellikle cumhurbaşkanının görev ve yetkilerinde açıkça ortaya çıkmış, cumhurbaşkanı sürekli olarak Marunilerden seçilmiştir. Cumhurbaşkanını sahip olduğu yetkililer Başbakanı ve kabine üyelerini aday göstermesi ve bakanlar kuruluna başkanlık edebilmesi sıkıntılı görülen yetkilerden bazılarıdır. Bu durum Lübnan'da iç savaşa giden süreçte de çok etkili olmuştur (Diss ve Steffen, 2017: 2). 


\section{1975 Lübnan İç Savaşı ve Temsil Sorunu}

Osmanlı'nın son dönemleri de dâhil olmak üzere Fransız işgali ve bağımsızlık sonrası dönemde sürekli olarak mezhepler ve etnik yapısı üzerinden kutuplaşan Lübnan, 1975 yılında yine etnik siyasi ve mezhebe dayalı karakterler üzerinden iç savaşın içine düşmüştür. Savaş boyunca genel olarak ülke "Lübnan Cephesi”" (el-Cebhetü'l-Lübnaniyye) ve "Lübnan ulusal hareketi" (el-hareketü'l-vataniyyetü'lLübnaniyye) etrafinda kutuplaşmıştır.

İç savaş boyunca adından en çok söz ettiren grup Arap milliyetçiliği temelinde politikalar izleyen Dürzi lider Kemal Canpolat'ın önderlik ettiği Lübnan Ulusal Hareketi olmuştur. Bu grup kendi içerisinde Arap Milliyetçisi, solcu ve Suriye ulusalcılarını da barındırmaktaydı. Çoğu kaynakta Müslüman Solcu Hareket olarak zikredilmekle birlikte (Moumneh, 2019: 51), iç savaş esnasında Müslüman, Dürzi, Şii ve solcu Hristiyan birlikteliğinin çatı yapısı olmuştur/olmaya çalışmıştır. Bu hareket aynı zamanda Filistin kurtuluş örgütünü de desteklemiş, özellikle iç savaşın ilk yıllarında savaşın iki ana akımından birisini temsil etmiştir.

Lübnan iç savaşının ilk dönemleri itibari ile etkin olan ikinci taraf Kamil Şemun' un etrafında toplanan Lübnan Cephesi'dir. Cephe hareketi, daha ziyade 1932 yılında yapılan nüfus sayımına göre Lübnan'daki çoğunluğu oluşturan Maruni Hristiyanlar tarafından ihdas edilmişti. Filistinli göçmenlerin ülkeye yerleşmesiyle demografik yapının değişmesinden rahatsız olan Marunîler, Filistinlilerin Lübnan topraklarından İsrail' e karşı yürüttüğü silahlı operasyonlardan rahatsız olduğunu deklare etmişlerdir (Moumneh, 2019: 140,141).

Lübnan'da mezkûr iki grup etrafından şekillenen iç savaşın tarafları aslında birdenbire yapılanmıș değildi. Öncelikle devletin bağımsızlığını kazanması ile birlikte ülkede Hristiyan üstünlüğünün yasal olarak kabul edilmiş olmas1, buna karşın özellikle Müslüman ve dinden bağımsız sol kimliğe sahip grupların yeni bir nüfus sayımı istemeleriyle ciddi bir sürtüşmeyi beraberinde getirmiştir. $\mathrm{Bu}$ taleplerin genelde Hristiyanların özelde ise Marunîlerin nüfuzunu bitirecek olması, bu grupların ciddi bir tehdit olarak algılanması sonucunu doğurmuştur. Yaşanan olaylara bu çerçeveden bakıldığında Lübnan'da gerçekleşen iç savaşın batılı kaynaklarda yansıtıldığı gibi salt bir MüslümanHristiyan savaşından çok daha öte bir anlam taşıdığı ortaya çıkmaktadır.

\subsection{Taif Anlaşması ve Temsil'de Yeni Dağılım}

Lübnan'da yaşanan iç savaş 1989 yılında Suudi Arabistan'ın Taif şehrinde imzalanan ve kaynaklarda Taif Anlaşması olarak geçen ittifakla sona ermiştir. Taraflardan birisinin de Suriye olduğu bu anlaşma, Lübnan'da uzun yıllar sürecek bir vesayeti beraberinde getirmiştir. Bu anlaşma ile 6'ya 5 temsil oranının Müslümanlar ve Hristiyanlar arasında yarı yarıya olacak şekilde değiştirilmesi, Hristiyan cumhurbaşkanının yetkileri kısıtlanması, Müslüman Sünni olan başbakanın yetkileri arttırılması ve Şiilerden seçilen Meclis başkanının görev süresinin uzatılması gibi birtakım değişiklikler gündeme gelmiştir. Fakat bu anlaşmanın Lübnan'a çok büyük bir yenilik getirdiğini söylemek zordur Lübnan'a görece olarak bir istikrar getirdiği söylenebilirse de özünde Müslüman-Hristiyan ayrımına dayalı düzen devam ettirilmiștir. Nitekim Lübnan'da mevcut ana sorunlar ve temsilden kaynaklanan krizler çözülmemiş, neticede Lübnan'daki mevcut politik sistem dine ve mezhebe dayalı kimlikler üzerinden kendisini tanımlamaya devam edegelmiştir. Taif Anlaşmasının temsilciler meclisi özelinde getirdiği yenilikleri ana hatları ile özetleyecek olursak (Taif Anlaşma Metni, www.presidency.gov.lb);

1- Meclis başkanı ve vekilleri seçildikleri dönem süresi boyunca görev yaparlar.

2- Meclis bir defaya mahsus olmak üzere 10 vekilin dilekçesiyle iki yıl sonra yapılan ilk oturumda meclis başkanını veya vekillerinden herhangi birisini oyların üçte ikisiyle görevden alabilir. Görevden alımın gerçekleşmesiyle meclis yeni başkan veya görevden alınan vekili seçmek üzere acilen toplanır.

3- Seçim çevreleri illerdir. Meclis ise mezheplerden bağımsız olarak aşağıda belirtilen kurallara göre şekillendirilmelidir:

- Vekil sayısı Müslümanlar ile Hristiyanlar arasında eşit şekilde olmalıdır.

- Mecliste Müslüman ve Hristiyan toplumları arasında orantılı dağılım sağlanmalıdır.

- Milletvekillikleri bölgeler arasında orantılı dağılım gerçekleştirilmelidir.

4- Hristiyan ve Müslümanlar arasında eşit olarak dağıtılacak olan parlamento koltuk sayısı 108'e yükseltilmeli. Bu belge ile ortaya çıkan merkezler veya ilan edilmeden önce dolan merkezler, kurulması planlanan milli ittifak tarafindan bir kereye mahsus olarak doldurulmalıdır.

5- Mezhebî ve etnik olmayan esaslarla, millî bir ruhla seçilen birinci meclisten sonra belli ailelerden seçilen kanaat önderleri meclisi kurulmalı ve bu meclisin görevi sadece ulusal güvenlik ile alakalı konularla sınırlı olmalıdır.

Taif Anlaşması' nda yer alan reformların önemli bir kısmı gerçekleşmemiştir. Örneğin kanaat önderlerinden oluşturulması planlanan İstişare Meclisi kurulmadığı gibi seçim sisteminde temsil oranına yönelik düşünülen düzenlemelerin gerçekleşmemesi nedeniyle seçimler de mezhebî ve etnik kökenlerden tecrit edilememiştir (AlAloosy, 2020: 69).

Seçim kanunu ile ilgili olarak Taif Anlaşması'nda zikredilen ve âdeta antlaşmanın merkezinde yer alan aşağıdaki maddeler de yürürlüğe sokulamamıştır:

- Meclis seçimleri il bazlı yeni bir seçim kanunu ile gerçekleşir.

- Bütün halk kitlelerin doğru ve etkin bir şekilde temsil edilmesi ve Lübnan halkının kardeşçe yaşamasının ön planda tutulması.

- İdari düzenin toprak, halk ve kurumların birliğini sağlayacak şekilde yeniden düzenlenmesi.

Sonuç olarak Taif sonrası Lübnan'da yeniden ihdas edilmeye çalışılan siyasal sistem, ülkede var olan büyük sosyoekonomik sıkıntıları ve bu sıkıntılar üzerinden varlığını sürdüren yapıyı değiştirmemiştir. $\mathrm{Bu}$, anlaşma sonrası yapılan seçimlerde seçim öncesi ve sonrası tartışmalarda daha net olarak görülmektedir. 
Lübnan'da en son 1972 yılında yapılmış olan genel seçimler, tekrar ancak 20 y1l sonra, 1992 yılının yazında yapılabilmiştir. Seçimlere girilmeden önce 1992 yılında çıkarılan 154/92 numaralı kanun, 26 Nisan 1960 tarihinde çıkarılmış olan ve çoğunluk sistemine dayanan seçim kanununu değiştirilmiştir. Fakat bu değişiklikler içerisinde Taif Anlaşması'nın işaret ettiği birçok madde uygulanmamıştır. Yapılan değişikliklerde meclis koltuk sayısının 128'e yükseltilmesi, seçim çevreleri olarak illerin belirlenmesi, koltukların Müslümanlar ve Hristiyanlar arasında eşit olarak paylaştırılması karara bağlanmıştır (Geukjian, 2016: 59). Müslümanlar kendi aralarında Sünni ve Şiilere 27 koltuk olacak şekilde paylaşım yapılmasını karara bağlamıştı. Buna rağmen özellikle Hristiyanlar bu paylaşım mantığı kabul etmediği gibi seçimler Hristiyanların çoğu tarafından boykot edilmiştir. Adil temsil hakkı üzerinden başlattıkları bu şikâyetlerini 2018 yılına kadar devam ettirmişlerdir. Bu adil temsil istekleri 2018 seçimleri öncesi yapılan değişiklik sonrasında son bulmuştur (Rabil, 2011: 90).

1992 seçimleri genel olarak değerlendirildiğinde 128 sandalyenin 92 tanesi bağımsız olarak seçimlere giren adaylardan oluştuğu görülmektedir. Buna karşılık parlamentoda en baskın bloğu 8 milletvekili ile ilk defa seçimlere katılan Hizbullah grubu oluşturmuş, eskiden beri mevcut olmasına rağmen varlığını gösteremeyen, iç savaş sonrası güçlenen Suriye Sosyal Milliyetçi Partisi (elHizbu's-Suri'l-kavmi'l-ictimâî) ise 6 milletvekili ile ikinci en büyük blokta yer almıştır. Seçimlere blok olarak girerek 5'er milletvekili yerleştiren diğer iki parti İlerici Sosyalist Parti (el-Hizbu't-takaddumi'l-İştiraki) ve Emel Hareketi (Hareketü'l-Emel) olmuştur(Khazin, 1998).

\begin{tabular}{|c|c|c|c|}
\hline Mezhepler & $\begin{array}{l}\text { Mecliste } \\
\text { sandalye } \\
\text { sayis1 }\end{array}$ & Aday Sayısı & $\begin{array}{l}\text { Adayların } \\
\text { Koltuklara } \\
\text { Oran1 }\end{array}$ \\
\hline Sünni & 27 & 211 & Tem.81 \\
\hline Şii & 27 & 185 & Haz.85 \\
\hline Dürzi & 8 & 39 & Nis.88 \\
\hline Alevi & 2 & 4 & 2.00 \\
\hline $\begin{array}{l}\text { Müslüman } \\
\text { Toplam }\end{array}$ & 64 & 439 & Haz.86 \\
\hline Marunî & 34 & 102 & 3.00 \\
\hline $\begin{array}{l}\text { Ortodoks } \\
\text { Rum }\end{array}$ & 14 & 57 & 4.Tem \\
\hline Katolik Rum & 8 & 24 & 3.00 \\
\hline $\begin{array}{l}\text { Ermeni } \\
\text { Ortodoks }\end{array}$ & 5 & 7 & Oca.40 \\
\hline $\begin{array}{l}\text { Ermeni } \\
\text { Katolik }\end{array}$ & 1 & 1 & 1.00 \\
\hline Protestan & 1 & 4 & 4.00 \\
\hline Azınliklar & 1 & 5 & 5.00 \\
\hline $\begin{array}{l}\text { Hristiyan } \\
\text { Toplam }\end{array}$ & 64 & 187 & Şub.92 \\
\hline $\begin{array}{l}\text { Genel } \\
\text { Toplam }\end{array}$ & 128 & 639 & Nis.99 \\
\hline \multicolumn{4}{|c|}{$\begin{array}{l}\text { Not: Kayıtlı birçok aday seçim günü adaylıktan çekilmiş } \\
\text { olmasına rağmen bunlar iç işleri bakanlığının kayıtlarından } \\
\text { düşürülmemiştir. Bu veriler iç işleri bakanlığının verilerine } \\
\text { göre düzenlenmiştir. } \\
\text { Kaynak: Figures for the number of candidates are from La } \\
\text { Lettre de Cassandre, August 1992, s. } 10 \text { ve September 1992, } \\
\text { s.14. Aktaran, Khazin, } 1998\end{array}$} \\
\hline
\end{tabular}

Yukarıdaki tablo, 1992 seçimlerinde her bir mezhebe mecliste verilen sandalye sayısını ve her bir mezhebin sandalye sayısına göre vekil adaylığına başvuru sayısını göstermektedir. Müslümanların seçime yönelik teveccühünün Hristiyanlarınkine nispetle iki kattan fazla olduğunu sandalye başına başvuran aday oranından görülebilmektedir. Müslümanlar içerisinde Sünni Müslümanların, Hristiyan nüfus içerisinde ise Ortodoks Rumların rağbeti daha fazla olmuştur.

Seçim sonuçlarına bakıldığında 1992 yılı seçimleri Lübnan iç savaşı sonrasında ülkedeki siyasal İslam’ın yükselişinin izlerini taşıdığı görülmektedir. Nitekim Hizbullah ve Lübnan Müslüman Kardeşleri siyasi arenada zahiren görünmüş, Suriye Sosyal Milliyetçi Partisi'nin de mecliste bir güç olarak doğması ile Müslüman kesimi temsil eden blokların çoğunluğunun Suriye rejimine bağlı veya en azından düşman olmadığı ortaya çıkmıştır. Diğer taraftan seçimlerde Hristiyanların iç savaş sırasında Filistin Kurtuluş Örgütü'ne ve Suriye ordusuna karşı kurdukları Lübnan Güçleri (ElKuvvetü'l-Lübnaniyye), 1992 seçimlerini Hristiyan tarafların küçültülmeye çalışıldığı ve Suriye'nin etkisinin arttırıldı̆̆ 1 bir seçim olarak değerlendirmişlerdir (Norton, 2007: 480-81). Aslında bütün bunlar ve yeni seçim kanunu Lübnanlıların siyasi olarak yeniden ayrışmasına neden olmuştur. $\mathrm{Bu}$ minvalde 1992 yılı seçimleri şöyle değerlendirilebilir:

- Taif Anlaşması ile Lübnan'da etkisini arttıran Suriye'nin vesayeti altında yapılan bu seçimlerde Suriye'nin kendisine tabi bir meclis çıkartacağı korkusu hâkim olmuştur. Bu nedenle hedefin 1995 yılında seçilecek cumhurbaşkanının seçilmesi değil, bu cumhurbaşkanın kim olacağının belirlenmesiydi.

- Seçilmiş meclisten öncelikli olarak 1991 yılında başlayan Orta Doğu barış müzakerelerinde Suriye ile beraber bir tutum sergilemesi ve Lübnan'da Suriye'nin çıkarlarına aykırı bir tutumun ortaya çıkmasına engel olması beklenmektedir.

- Seçimlerle meclise giren İslamcılar siyasete dahil edilmiş ve siyasetin içinde önemli bir aktör olmakla birlikte sürekli Suriye'nin Lübnan'daki kolu olarak sayılmışlardır.

1992 yılını takip eden dönemde 1996 ve 2000 seçimleri de gerek şartlar açısından ve gerekse sonuçları açısından çok farklı olmamıştır. Suriye'nin vesayeti altında gerçekleşen bu üç seçimi de Suriye Lübnan'daki varlığını meşru göstermek için hem manipüle etmiş hem de araçsallaştırmıştır. 1992 yılında değiştirilemeyen seçim kanununda bu dönemi takiben yine herhangi bir değişiklik söz konusu olmamıştır. Özellikle ülke içerisinde iç savaş ile derinleșmiş olan mezhepsel ve etnik bölünmeyi minimize edebilmek için Taif’te büyük seçim bölgelerinin oluşturulması gerektiği konusunda fikir birliğine varılmıştı. Fakat 1992 yılında zorunluluktan dolayı kazalar üzerinden belirlenen ve ileride değiştirilecek denilen seçim bölgeleri değiştirilmemiştir. Seçim bölgeleri küçüldükçe mezhebî ve etnik kimlik üzerinden tanımlanan bir seçmen davranışı profili ortaya çıkmıştır. Bu durumdan da en çok Suriye istifade etmiştir (Osoegawa, 2013).

2000'li yıllar artık Lübnan'da birçok şeyin eskisi gibi olmayacağının habercisiydi. Öncelikle Güney Lübnan'da 
asker bulunduran İsrail askerlerini çekeceğini deklare etti. $\mathrm{Bu}$ durum ülkede Suriye varlığına karşı duran Marunî ve Dürzileri hareketlendirmiştir. Uzun bir süre Suriye karşıtı gösteriler yapılmış ve 2001 yılında Suriye'nin Beyrut'tan çekilmesi sağlanmıştır. Bu durum Suriye karşıtı muhalifleri bir araya getirmesi açısından önem arz etmektedir. Suriye karşıtlığı Lübnan'da asırları aşan Maruni- Dürzi gerginliğini de bitirme noktasına getirmiştir (Tür ve Ayhan, 2008: 6).

2005 yılı, Lübnan siyasi tarihi açısından ciddi bir dönüm noktasının yaşandığı bir yıl olarak dikkat çekmektedir. Öncelikle yıllarca ülkenin başbakanlığını yapmış olan Refik Hariri bir suikastta öldürülmüştür. Bu suikast ile birlikte gerek BM gerekse ABD doğrudan Lübnan'da varlığını hissettirmiş ve Suriye'nin Lübnan'daki askeri varlığını sonlandırmışlardır. ABD'nin Lübnan'daki Hariri suikastıyla birlikte oluşturduğu baskıdan cesaretlenerek sokaklara inen halk hareketine "Sedir Devrimi” (Sevratu'l-Erz) denmiştir. Suriye'nin çekilmesinin hemen ardından ülkede hüküm süren Suriye yanlısı hükûmet istifa etmiştir. $\mathrm{Bu}$ istifanın hemen ardından yapılan seçimlerde ise ABD doğrudan gözlemci göndermiş ve iç savaş sonrasında ilk defa Suriye bu seçimlerde etkin bir rol üstlenememiştir (Köprülü ve Ebrem, 2013: 15,16; Kurtuluş, 2009: ).

Refik Hariri Suikasti ve Suriye'nin Lübnan'dan askerlerini çekmesi olayı ülkede toplumsal ve siyasi arenada önemli birtakım yeni kutuplaşmalara sebep olmuştur. Bunların ön plana çıkan ve günümüze kadar etkisini gösteren ikisi 8 Mart (Tahalufu Azhar) ve 14 Mart (Tahalufu 8 Azhar) gruplarıdır. Suriye karşıtı Sedir gösterilerini tepki olarak 8 Mart 2005 tarihinde Beyrut'ta birtakım gösteriler düzenlenmiştir. $\mathrm{Bu}$ gösterilere Hizbullah, Emel Hareketi, Marunî Ulusalc1lar, Dürzi demokratlar, Sünni Gruplar, Solcu Ermeniler ve Aleviler katılmışlardır. Bu gösterilerde Sedir Devrimi'nin tam tersine Suriye desteklenirken Lübnan'a yaptığı katkılardan dolayı Suriye'ye teşekkür edilmiştir. Parti ve grupların mezkûr gösterilere katılımı, daha sonra 8 Mart İttifakı olarak anılmıştır ( Köprülü ve Ebrem, 2013: 17).

Sedir gösterilerine tepki olarak yapılan 8 Mart gösterilerine de birtakım reaksiyonlar gündeme gelmiştir. Bu bağlamda Saad Hariri'nin başını çektiği Gelecek Hareketi, Emin Cumeyyil' in başkanlığını yaptığı Marunîlerin Ketaib Hareketi, Velid Canpolat'ın başını çektiği Sosyalist Dürziler, Semir Ceca' nın önderliğindeki Marunî Lübnan Güçleri grubu ve son olarak Müslüman Kardeşlerin kolu olan Cemaati İslami hareketi 14 Mart'ta meydanlarda protesto gösterileri yapmışlardır. Bu olaydan sonra 14 Mart grubu olarak anılmaya başlanmışlardır. Bu gösterilerdeki temel talepler ise eski Suriye yanlısı Cumhurbaşkanı Emil Lahud' un sürgüne gönderilmesi, Hariri Suikastı için özel bir mahkemenin kurulması ve Lübnan sınırlarının netleştirilmesi olmuştur (Kurtulus, 2009: 197-198).

2005 seçimlerinde ortaya çıkan gruplar içerisinde bazı kişi ve grupların geçmişlerinden bağımsız birtakım tercihlerde bulundukları da görülmektedir. Mesela General Mişel Avn, beklenildiği gibi Suriye muhaliflerinin şekillendirdiği 14 Mart koalisyonu ile değil, Hizbullah'la beraber hareket eden 8 Mart ittifakı içerisinde etkili bir rol oynamıştır. İslami kanatta ise, Hariri'nin oğlunun liderliğindeki grup, kuzeyde bulunan Sünnî oyların çoğunu elde etmiş, güneyde bulunan Şii oylarını ise Suriye destekçisi güçler elde etmiştir. Sonuç olarak seçimlerin en başarılı tarafı 14 Mart ittifakı yani Sedir Devrimi adı verilen guruplar olmuştur.

\subsection{Doha İttifak1}

2005 seçimleri sonucunda meclise gelen vekillerin görev süresi dolmadan önce Mayıs 2008 tarihinde karşıt taraflar arasında Beyrut ve Cebel bölgelerinde ortaya çıkan silahlı çatışmalar, 1990 yılında biten iç savaş sonrası en tehlikeli ve en şiddetli çatışmalar olarak kayda geçmiştir. Bu gerginliğin nedeni ise hükûmetin Hizbullah tarafından kullanılan sinyal dağıtım araçlarının elinden alınması ve Beyrut uluslararası havaalanında emniyet sorumlusu olan ve Hizbullah'a yakınlığıyla bilinen albayın görevden alınması olmuştur. $\mathrm{Bu}$ durum millî direnişi destekleyen bakanlar kurulu kararına ters olarak görülmüş ve Hizbullah militanları meydanlara dökmüştür.

2008 yılında yaşanan olayların başlangıcı muhalefetin hükûmeti meşru bir hükûmet olarak görmemesinden dolayı ona karşı güç kullanmayı uygun bulmasından kaynaklanmaktadır. Aslında kutuplaşmanın bu kadar keskin olduğu ortamlarda bu durum çok da sürpriz değildir. Sokak olaylarının patlak vermesi ve 62 kişinin ölümünün ardından hükûmet anlaşmazlık yaratan iki kararı geri alınca durum düzelmiştir (Tucker, 2017: 195).

Lübnan'da birbirleriyle takriben 18 aydır çatışan grupların Doha'da yaptıkları toplantı ve akabindeki anlaşma metninde temel olarak aşağıdaki maddeler üzerinde anlaşma sağlanılmıştır (BM GK, Belge NO: 2008/s578 );

- 24 saat içerisinde taraflar vekiller aracılığıyla usule göre meclisi toplantıya çağırıp cumhurbaşkanı olarak ortak aday General Mişel Avn' 1 aday göstereceklerdir.

- Kurulacak olan millî ittifak hükûmetinin 30 bakanlık ile kurulmasına, hükûmet kanadına 16, muhalefete 11, cumhurbaşkanına 3 bakan verilmesi, hiçbir tarafın istifa etmeyeceği ve hükûmete engel olmayacağı üzerine ittifak edilmiştir.

- 1960 yılı seçim kanunun uygulanması ve dolayısıyla her ilçenin bir seçim dairesi olarak kabul edilmesine karar verilmiştir.

Lübnan'daki çatışmalı siyasi grupların Katar'ın başkenti Doha'da Arap Birliği'nin aracılığı ile bir araya gelerek yaptıkları bu anlaşma, muhaliflerin zaferi olarak değerlendirilmiştir. Lübnan'ı Doha Anlaşması'na götüren süreç ve Doha'dan çıkan sonuç, aslında ülkenin siyasi mezhepçi yapısını daha da derinleştirmiştir. Ülke içerisinde güç dağılımındaki mezhebe dayalı anlayış; siyasi, kültürel ve ekonomik özerkliklerini muhafaza ettiği gibi mezhepsel grupların egemenlikleri tasdiklenmiş ve daha da yerleşmiştir.

Doha Anlaşması'nın hemen akabinde Lübnan'da gerçekleşen genel seçimlerden nasıl bir seçim sonucunun çıkacağı oldukça önem kazanmıştır. Bu seçimlere giderken ilk dikkat çeken husus, Rum Ortodoks gruplarının lideri Michel Murr' un seçim öncesi taraf değiştirmesi olmuştur. Ayrıca Cumhurbaşkanı Mişel Süleyman'da yeni seçimlerden önce tarafını değiştirerek 14 Mart ittifakını desteklemeye başlamıştır. Hatta danışmanı milletvekili adayı olmuş, Süleyman'da aleni olarak ona oy istemiştir (Ayhan, 2009: 44)

2009 seçimlerini önceki seçimlerinden ayıran bir özellik olarak taşımalı oy sistemi ile dışarıdan getirilen seçmenlerin oy kullanmasının, seçim sonuçlarına doğrudan etki ettiği 
düşünülmektedir. Söz gelimi; sadece Türkiye'den 1-6 Haziran 2009 tarihleri arasında 5 bin civarında Lübnanlı oy kullanmak için Lübnan'a gitmiştir. Diğer yandan 14 Mart İttifakı'nın özellikle Hristiyan bölgelerde 8 Mart İttifakı'na nazaran daha fazla oy almış olması bu seçimin ayırt edici diğer bir yönünü teşkil etmektedir (A.g.e.: 44).

2009 seçimlerine ilişkin bir diğer arızi durumda, seçimde alınan oyların meclisteki grupların temsilinde yaşanmış olmasıdır. 128 sandalyenin 71'ini elde etmiş olan 14 Mart İttifakı, seçimde yaklaşık 700 bin civarında bir oy almış iken 850 bin civarında oya sahip 8 Mart grubu mecliste 57 sandalye elde etmiştir (Ayhan, 2009: 46) . Böyle bir ortamda 2018 yılında yapılacak seçimine kadar seçimin gerçek galibinin kim olduğuna ilişkin tartışmalar devam edegelmiştir.

Son olarak 2009 seçimleri diğer seçimlerden farklı olarak uluslararası düzeyde çok yakından takip edilen ve bölgesel ve küresel aktörlerin taraf aldığı bir seçim olmuştur. Bu seçim, özellikle Sünnîler ve Şiîler arasındaki gerginliklerin bir yansıması olarak görünmüş, bu süreçte Dürzi gruplar Sünnîlerin yanında yer almıștır. Maruni ailelerden küçük bir azınlık özellikle Hizbullah'ın İran ile olan ilişkisine vurgu yaparak Arap Kimliği ve Hristiyan mezhebinin bu ilişkiden ciddi zarar göreceğini deklare etmiștir. Buna karşılık Maruni kesimin büyük bir kesimi, Şiiler ile ittifak kurmuş ve 2009 seçimlerinde hep birlikte 8 Mart İttifakı'na destek vermişlerdir. D1ş politikada ise özellikle 14 Mart İttifakı Suudi Arabistan tarafından iktisadi olarak desteklenmesinin yanı sıra Mısır medyası, ABD ve İsrail kanadı çok açık bir şekilde 14 Mart İttifakı'nı desteklediklerini açıklamışlardır.

\section{2018 Seçimleri ve Lübnan'da Temsil Sorunu}

Lübnan'daki Lübnan'daki 2009 seçimi, bölgesel ve küresel aktörlerin de açıktan taraf edindiği bir siyasi arenaya dönmüş, bu durum tabii olarak seçimin bölgesel ve küresel olarak kazananları ve kaybedenlerini ortaya çıkardığı gibi 2009 sonrası dönemin çok daha sancılı geçmesine sebep olmuştur. Nitekim daha bir y1l sonra hükûmetin güçlü ortaklarından Velid Canpolat hükûmetten çekildiğini açıklamasının ardından diş aktörlerin devreye girmesi, zaten kendi iç kutuplaşması çok keskin olan Lübnan'1 yeni bir istikrarsızlık sürecine sokarken uzmanlar iç savaşın patlak vermesinden korkmaktaydilar (Badrakhan, 2013).

Lübnan'da normal şartlar altında 2013 yılında yapılması gereken genel seçimler yapılamamış ve siyasi kutuplaşmalardan ötürü 2 defa, teknik sebeplerden dolayı da bir kez seçimler ertelenmiştir. Seçimlerin daimî tehiri, hükûmetin 2013 sonrası politik meşruiyetinin de sorgulanmasına sebebiyet vermiştir. $\mathrm{Bu}$ süreçte salt genel seçimler değil, 2014 yılında yapılması gereken cumhurbaşkanlığı seçimleri de gerçekleşmemiş ve 2016'nın sonuna sarkmıştır.

Siyasal olarak ortaya çıkan bu istikrarsız yapıyı Lübnan'da tarihi bir derinliği olan komşu ülke Suriye'deki iç savaş daha da sarsmıştır. Suriye'de yaşanan iç savaş Lübnan'da ezelden beri var olan istikrarsız yapıyı ve ideolojik bölünmüşlüğü daha da derinleştirmiştir. Diğer yandan yeni gelen mülteciler ve ülkenin kendi ekonomik yapısındaki sıkıntılar iktisadi krizi ve güvenlik sorunlarını tetiklemiştir. Sosyal, iktisadi ve siyasi yapıdaki sıkıntılar, halkın siyasilerine olan güvenini sarstığı gibi halk nezdinde derin bir umutsuzluğa sebep olmuştur.

Konuya ilişkin temas edilmesi gereken önemli bir nokta da Lübnan'da belli bir süre varlığını hissettiren ve daha sonra çekilen Suriye konusunda halkın iki kutba ayrılmış olmasıdır. Suriye'de iç savaşın patlak vermesiyle birlikte bir taraf Esad'1 desteklerken diğer grup devrimcileri desteklemiştir. Lübnan, özellikle Hizbullah'ın İran talimatıyla Suriye'ye girmesiyle Suriye devriminden daha derin bir şekilde etkilenmiştir. Hizbullah'ın desteği ile Suriye rejimi, Lübnan sınırı boyunca birçok bölgeyi devrimcilerden geri almıştır. $\mathrm{Bu}$ durum Suriye devrimini destekleyen Lübnan'daki Sünnî kesimin Hizbullah'a karşı kinini arttırmıştır (Bkz: Young, 2014).

Bütün bu yaşananların yanı sıra seçimlerin uzun süre ertelenmesinin altında, Hristiyanların Taif Anlaşması'ndan beri seçim yasasına yönelik dile getirdikleri şikâyetler de yer almaktadır. 2018 yılının ilk çeyreğinde uzun süredir devam eden tartışmalar nihayete ermiş ve yeni seçim yasası yürürlüğe girmiştir. Yeni seçim yasasının en önemli yenilikleri, daha önce uygulanan çoğunluk sisteminin yerine nispî temsil sistemine göre seçimlerin gerçekleştirilecek olması, yıllardır dile getirildiği üzere 26 seçim bölgesinin 15 'e indirilerek seçim çevrelerinin büyütülmesi ve tercihli oy sistemine geçilerek seçmenlerin ilan edilen seçim listelerinden sadece bir adaya oy vermesinin kararlaştırılmış olmasıdır (Hyndman-Rizk, 2020: 89).

Yapılan seçimlere sonuçları açısından bakıldığında; Suriye'nin müttefiki olarak 8 Mart hareketinin liderliğini yürüten Hizbullah'ın çok büyük kazanımlar elde ettiği görülmektedir. Hizbullah mecliste sahip olduğu koltuklarını korumuş ve müttefikleri de diğer bölgelerde büyük kazanımlar elde etmişlerdir. Sayıları 15 olan seçim dairelerinin 14'ünüde Hizbullah ve müttefikleri kazanmış ve meclis koltuklarının yarısından fazlasını elde etmişlerdir. Lübnan'da ve bölgede İran'ın nüfuz aracı olarak değerlendirilen Hizbullah'ın başarısı, Tahran'ın sadece Lübnan'da değil, bölgedeki etkisini de daha fazla arttıracağına yönelik spekülasyonlara sebep olmuştur.

14 Mart bloku ve onun liderliğini yapan Hariri’nin Gelecek Partisi ise bu son seçimlerin kaybedeni olmuş ve 33 olan koltuk sayısı 21'ye kadar düşmüştür. Buna rağmen Hariri, meclisteki Sünnî gurubun lideri olarak 128 koltuk içerisinde en çok koltuk sayısına sahip Müslüman grup olmuş ve hükûmeti kurmak için yine en güçlü aday hâline gelmiştir. Diğer taraftan Hizbullah'a karşı olan Hristiyan Lübnan Güçleri Partisi 15 koltukla koltuk sayısını ikiye katlamıştır (Öztürk, 2018: 66).

\section{Sonuç}

Lübnan Orta Doğu'nun tüm karmaşık özelliklerini tek başına uhdesinde barındıran bir yapıya sahiptir. Öncelikle etnik ve dinî açıdan en karmaşık toprakların başında gelmektedir. Osmanlı son dönemlerinde Osmanlı toprakları bir bir kendisinden koparılırken her bir yerde işgalciler belli bir azınlığa yaslanarak o ülkelerde kontrollerini yürütmeye çalışmışlardır. Bu durum Lübnan için de geçerli olmakla beraber bu ülke içerisinde dikkatten kaçan temel özellik bu toprakların adeta azınlıkların toplamından oluşuyor olmasıdır. Bu ülkede Hristiyan sadece bir Hristiyan olmadığı gibi Müslümanlar da sadece birer Müslüman değildir. 
Osmanlı toprakları emperyalistler tarafından işgal edilmeye başlanıldığı zaman önce etnik sonra dinî azınlıkların kışkırtılmalarıyla süreç yönetilmeye çalışılmıştır. Lübnan Osmanlı döneminde özellikle ayan denilen taşranın önde gelenleri, eskiden idarecilik yapmış ya da içinde bulunduğu topluluk içerisinde ön plana çıkmış saygı görmekte olan insanların öne çıktığı bir anlayışa sahipti. Bunlar merkezden gelen vali ve yöneticilerin hâkimiyeti altında toplumu idare etmekteydiler. Elbette böyle bir ortamda her bir topluluk kendi inancına, mezhebine göre ön plana çıkardıkları etkin kişileri kendilerinin temsilcisi olarak merkezî otoriteyle muhatap ettiriyordu.

19.yüzyılın karmaşık ortamında Avrupalı devletlerin Osmanlı'nın iç işlerine karıştıkları bir ortamda burada yaşayan azınlıkların hemen hemen tamamı farklı devletler için buradaki meselelere müdahil olmak için araçsallaştırılmıştır. Öncelikle mikro düzeyde toplulukların kendilerini temsil ettikleri bir yerde üst kimlik olarak inşa edilen Hristiyanlık veya Müslümanlık birbirine düşmanlaşmış mezhepler arasında itilafa sebep olmuştur. Avrupa'nın 30 y1l veya bir asır boyunca birbirleriyle mezhepleri üzerinden savaşarak yaşadıkları travmalı sürece Lübnan Osmanlı sonrasında girmiştir/sokulmuştur.

Modern Lübnan tarihi incelendiğinde Lübnan'da var olan demografik yapısının artık daha henüz üzerin de ittifak edilmemiş bir temsil ve seçim sistemine dayandığ görülmektedir. Uzun yıllardır yapılan tüm çabalara rağmen 2020 yılında kurulan hükûmetin başbakanı ilk icraatlarından birisinin seçim sisteminin değiştirilmesi olacağını söylemektedir. Lübnan'da ulusal ittifakla beraber 1943 y1lında üzerinde ittifak edilen en temel prensip ülkenin Cumhurbaşkanının Marunî Hristiyan ve Başbakanın Sünni Müslüman ve meclis başkanı da Şiiler içerisinden seçilecektir. $\mathrm{Bu}$ temel prensip üzerinden aslında öncelikle Lübnan'da diş müdahalelerin kimler tarafindan kimler üzerinden ilerleyeceği de belirlenmiş olmaktaydı.

Lübnan toplumdaki temel çıkar çatışmalarının analiz edildiği ve bu çatışmaların dengelenmesi çabaları ülkedeki etnik, bölgesel, kültürel çatışmalar ve mezhebî bölünmüşlükleri sürekli olarak daha da derine itmiştir. Makro yaklaşımların üzerinde ittifak ettikleri prensiplere göre bireyler tercihlerini etnik ve mezhebi aidiyetlerine göre belirleyebilmektedir. Fakat bu durum Lübnan özelinde Hariri Suikasti, Suriye'nin Lübnan'dan çekilmesi ve akabinde gelen Doha Anlaşması'na kadar devam etmiştir. Bu süreçle birlikte Lübnan toplumu tercihlerini yaparken artık olayları merkeze alarak her bir yeni olayda yeniden gruplana bir anlayışa dönüşmeye başlamıştır. Lübnan'ın günümüzdeki seçmen davranışlarını aslında Sosyopsikolojik yaklaşım daha iyi bir şekilde açıklamaktadır. Yani seçmen davranışlarını dönemlik tartışmalara yönelik politikacı davranışları ve bunlar ile bağlantılı olarak ortaya çıkan bir parti veya grup kimliği üzerinden açıklanmalıdır. Doha anlaşması aslında tam da böyle bir Lübnan doğurmuştur.

$\mathrm{Bu}$ durumun en önemli örneklerinden birisi özellikle Taif düzenine Hristiyanların haklarını yediğini söyleyerek karşı çıkarak 16 yıl sürgün hayatı yaşayan Mişel Avn Hariri suikastından sonra 2005 yılında ülkeye dönmüştür. Ancak döndükten sonra çoğunluğunu Hristiyanların oluşturduğu Suriye karşıtı blok olan 14 Mart grubunda değil Suriye destekçisi 8 Mart grubu ile siyaset yapmıştır. Bir diğer örnek olarak ise Rum Ortodoks'u olan Lübnanlı iş adamı ve siyasetçi Mişel Murr' un bu dönem içerisindeki siyasi tercihleri gösterilebilir. Suriye sonrası dönemde yapılan 2005 seçimlerinde Mişel Avn ile ve dolayısı ile 8 Mart bloku ile ittifak yapan Murr 2009 seçimlerinde 14 Mart ittifakı ile seçime girmiştir.

Son seçimlerde yine artık göstermiştir ki bir üst kimlik olarak Hristiyanlık ve Müslümanlık yeterli değildir. Hatta bu dinî kimliklerin altındaki mezhepler bile artık bir anlam ifade etmemektedir. Lübnan'da 2018 yılında yapılan seçimler ve sonrası göstermiştir ki Şiilere verilen 6 bakanlık Hizbullah ve Emel hareketi arasında nasıl dağıtılacağı kavgasına, Hristiyan Marunîlere verilen 11 bakanlık hangi Marunî aileler ve gruplar arasında pay dileceği kavgalarına sahne olmuştur. Yine bugüne kadar Sünnilere verilen 6 bakanlığı tek başına kullanan Hariri'nin Müstakbel partisinin bile otoritesi son seçimde 8 Mart bloku ile meclise giren 10 Sünni milletvekili tarafından sorgulanır olmuştur.

Sonuç olarak Lübnan'da artık seçmen davranışları ve temsil meselesi doğrudan mezheplere göre belirlenen ve şekillen bir olgu olmayı aşmıştır. Siyasi tercihler yeni olaylar ve bireyler üzerinden şekillenen ve neredeyse her yeni olay ve dönemde yeniden şekillenen bir davranış kalıbına dönüşmüştür. Bunlar bireylerin ve grupların sosyopsikolojik tavırları üzerinden açıklanabilmektedir. Lübnan aslında en karmaşık olduğu bir dönemde yapılan analizler göstermektedir ki bir aşıra yakın bir süredir Lübnan'ın üst kimliğini oluşmasına engel olan Mezhepçilik artık aşılmaya başlanmıştır. Bu durumda Lübnan belki de tarihinde ilk defa mezhep üstü bir üst kimlik oluşturmaya bu kadar yakın durmaktadır. Elbette böyle bir eşikte siyasi karar alıcıların kararları bu mezhep üstü siyasetin ne tarafa evrileceğini gösterecektir.

\section{Kaynakça}

Al-Aloosy, M. (2020). The Changing Ideology of Hezbollah. Springer Verlag.

Al-Khazin, F. (1998). Lebanon's First Postwar Parliamentary Election, 1992: An İmposed Choice. Centre for Lebanese Studies.

Arselân, Ş. (2011), Müdevvenetü Ahdâsi'l-âlemi'l-Arabî ve vakâi', Beyrut: Dâru't-takdîmiyye

Baaklini, A. I. Denoeux, G. \& Springborg, R. (1999). Legislative politics in the Arab world: The resurgence of democratic institutions. Lynne Rienner Publishers.

Badrakhan, A. (2013). Lebanon Seeking National Unity Government for Sectarian Tension, https://studies.aljazeera.net/en/reports/2013/04/201 3429103357611395.html en son erişim. 14.02.2020.

Bağlığlu, A. (2008). Lübnan'ın Tarihsel Dokusu ve Yönetim Anlayışındaki Mezhebi Etkiler. Fırat Üniversitesi İlahiyat Fakültesi Dergisi, 13(1), 1336.

Beyhem, M. C. (1968). El-Ahdü'l-muhdaram fî Suriye ve Lübnan, Beyrut: Dâru't-talîa.

Çelik, Ü. (2012). İç Çatışmalar ve Dış Müdahaleler Arasında Lübnan. History, 4, 1. 
Deringil, S. (2012). Conversion and Apostasy in the late Ottoman Empire. Cambridge University Press.

Diss, M. \& Steffen, F. (2017). The Distribution of Power in the Lebanese Parliament Revisited. GATE WP, 1723 .

Duman, O. (2006). Bir Orta-Doğu Buhranı Cebel-i Lübnan Olayları (1860-61). Mustafa Kemal Üniversitesi Sosyal Bilimler Enstitüsü Dergisi, 3(5).

Er-Rebî‘̂̂̀，A. (2014). El-İnkısâmu'l-vatanî li-Lübnânî fî ahdi'l-intidâbi'l-Fransî 1920-1943: Dirâsât târîhiyye, Irak: Câmiatü'l-Basriyye.

Geukjian, O. (2016). Lebanon After the Syrian Withdrawal: External Intervention, Power-sharing and Political Instability. Taylor \& Francis.

Harîk Î. (1982). Et-Tahavvulu's-siyâsî fî̀ târîhi Lübnani'lhadîs, Beyrut: Mektebetü Ehliyye.

Heraclides, A. and Dialla, A. (2015). Humanitarian İntervention İn The Long Nineteenth Century: Setting The Precedent. Manchester: Manchester University Press.

Keles, E. (2008). Cebel-İ Lübnan'da İki Kaymakamlı İdari Düzenin Uygulanması Ve 1850 Tarihli Nizamnâme. Tarih Araştırmaları Dergisi, 27(43), $131-158$

Köprülü N. ve Ebrem İlker Salih, (2013). Lübnan'da Çoklu Güç Paylaşımı ve Ortaklıkçı Demokrasi Zemininin Arap Ayaklanmaları Sonrası Geleceği, Akademik Ortadoğu, Cilt 8, Sayı 1

Kurtulus, E. N. (2009). 'The Cedar Revolution': Lebanese Independence and The Question of Collective SelfDetermination. British Journal of Middle Eastern Studies, 36(2), 195-214.

Landau, J. M. (1961). Elections in Lebanon. The Western Political Quarterly, 14(1), 120-147.

Lipset, S. M. \& Rokkan, S. (1967). Party Systems And Voter Alignments: Cross-National Perspectives (Vol. 7). Free Press.

Ziemer. K. (1978), Djibouti: Französisches Territorium der Afar nd Issa, içinde: Nuscheler, Franz ve Ziemer, Klaus, (1978) Die Wahl der Parlamente, Afrika Berlin/New York.

Young, W. Stebbins, D. Frederick, B. \& Al-Shahery, O. (2014). Spillover of the Syrian Conflict into Lebanon. In Spillover from the Conflict in Syria: An Assessment of the Factors that Aid and Impede the Spread of Violence. RAND Corporation.

Hyndman-Rizk, N. (2020). Lebanese Women at the Crossroads: Caught Between Sect and Nation. Lexington Books.

Öztürk, S. (2018). Ortadoğu'daki Gelişmeler Çerçevesinde Mukteda El Sadr ve Hareketinin Irak'ta Yükselişi.
Ma`oz, M. (1968). Ottoman Reform in Syria and Palestine, 1840-1861: The İmpact of The Tanzimat on Politics And Society. Clarendon Press.

Moumneh L. (2019), The Lebanese Forces: Emergence and Transformation of The Christian Resistance. Hamilton Books

Nisan, M. (2017). Politics And War in Lebanon: Unraveling The Enigma. Routledge.

Norton, A. R. (2007). The Role of Hezbollah in Lebanese Domestic Politics. The International Spectator, 42(4), 475-491.

Osoegawa, T. (2013). Syria And Lebanon: International Relations and Diplomacy in The Middle East. Bloomsbury Publishing.

Rabil, R. (2011). Religion, National İdentity, and Confessional Politics in Lebanon: The Challenge Of Islamism. Springer.

Rezzak, H. (1998) Lübnan Beyne'l-Vahde Ve'l-İnfisâl, Hezâim Müteaddide (1919-1927), Beyrut: Mektebetü Beysân.

Salîbî, Kemal S. (1996). Târîhu Lübnani'l-Hadîs, Beyrut: Dâru'n-Nehar.

Şuayb, A. (1987). Matâlibu Cebel: Âmilu'l-vahdeti'lmüsâvât fî̀ Lübnâni'l-kebîr, Beyrut: elMüessesetü'l-câmi'iyye

Tarbîn, A. (1968) Lübnân münzü ahdi'l-mutasarrifiyye ile'1intidâb, Kahire: Ma'hedü'd-dirâsâti'l-arabiyyeti'lalemiyye

Tucker, S. C. (Ed.). (2017). Modern Conflict in the Greater Middle East: A Country-by-Country Guide. ABCCLIO.

Tür, Ö. \& Ayhan, V. (2008). İçsel Dinamikler Ve Ulusal Aktörler Bağlamında Lübnan Krizinin Analizi. Akademik Orta Doğu, 3(1).

Zamir, M. (2014). The Secret Anglo-French War in the Middle East: Intelligence and Decolonization, 1940-1948. Routledge.

Güvenlik Çalışmaları Dergisi, Yı1: 20, Cilt: 20, Sayı: 1

\section{Internet Kaynakları}

http://www.presidency.gov.lb/Arabic/Pages/TaifAgreement .aspx (Son Erişim Tarihi: 01.03.2020),

Milli İttifak Belgesi'nin Tam Metni İçin Bkz. Lübnan Cumhurbaşkanlığı Sitesi, S.1, Ulaşabileceğiniz Link:

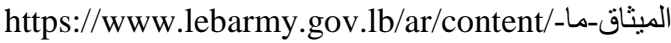

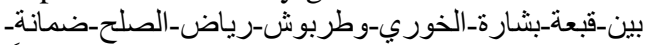
en son erişim 09.02.2020

BM güvenlik konseyi, 22/8/2008 tarihli sözlü bildiri, genel sekreterden katar daimî temsilcisine, belge no: 2008/s578 